\title{
Front Matter: Volume 8179
}

, "Front Matter: Volume 8179," Proc. SPIE 8179, SAR Image Analysis, Modeling, and Techniques XI, 817901 (25 October 2011); doi:

10.1117/12.918184

SPIE. Event: SPIE Remote Sensing, 2011, Prague, Czech Republic 


\title{
PROCEEDINGS OF SPIE
}

\section{SAR Image Analysis, Modeling, and Techniques $\mathrm{XI}$}

\author{
Claudia Notarnicola \\ Simonetta Paloscia \\ Nazzareno Pierdicca \\ Editors
}

21-22 September 2011

Prague, Czech Republic

Sponsored by

SPIE

Cooperating Organisations

EOS- European Optical Society

Remote Sensing and Photogrammetry Society (United Kingdom)

Published by

SPIE 
The papers included in this volume were part of the technical conference cited on the cover and title page. Papers were selected and subject to review by the editors and conference program committee. Some conference presentations may not be available for publication. The papers published in these proceedings reflect the work and thoughts of the authors and are published herein as submitted. The publisher is not responsible for the validity of the information or for any outcomes resulting from reliance thereon.

Please use the following format to cite material from this book:

Author(s), "Title of Paper," in SAR Image Analysis, Modeling, and Techniques XI, edited by Claudia Notarnicola, Simonetta Paloscia, Nazzareno Pierdicca, Proceedings of SPIE Vol. 8179 (SPIE, Bellingham, WA, 2011) Article CID Number.

ISSN 0277-786X

ISBN 9780819488060

Published by

SPIE

P.O. Box 10, Bellingham, Washington 98227-0010 USA

Telephone +1 3606763290 (Pacific Time) · Fax +1 3606471445

SPIE.org

Copyright (C) 2011, Society of Photo-Optical Instrumentation Engineers

Copying of material in this book for internal or personal use, or for the internal or personal use of specific clients, beyond the fair use provisions granted by the U.S. Copyright Law is authorized by SPIE subject to payment of copying fees. The Transactional Reporting Service base fee for this volume is $\$ 18.00$ per article (or portion thereof), which should be paid directly to the Copyright Clearance Center (CCC), 222 Rosewood Drive, Danvers, MA 01923. Payment may also be made electronically through CCC Online at copyright.com. Other copying for republication, resale, advertising or promotion, or any form of systematic or multiple reproduction of any material in this book is prohibited except with permission in writing from the publisher. The CCC fee code is 0277-786X/11/ \$18.00.

Printed in the United States of America.

Publication of record for individual papers is online in the SPIE Digital Library.

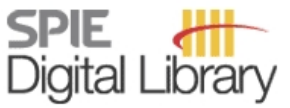

SPIEDigitalLibrary.org

Paper Numbering: Proceedings of SPIE follow an e-First publication model, with papers published first online and then in print and on CD-ROM. Papers are published as they are submitted and meet publication criteria. A unique, consistent, permanent citation identifier (CID) number is assigned to each article at the time of the first publication. Utilization of CIDs allows articles to be fully citable as soon as they are published online, and connects the same identifier to all online, print, and electronic versions of the publication. SPIE uses a six-digit CID article numbering system in which:

- The first four digits correspond to the SPIE volume number.

- The last two digits indicate publication order within the volume using a Base 36 numbering system employing both numerals and letters. These two-number sets start with 00, 01, 02, 03, 04, $05,06,07,08,09,0 A, 0 B \ldots 0 Z$, followed by 10-1Z, 20-2Z, etc.

The CID number appears on each page of the manuscript. The complete citation is used on the first page, and an abbreviated version on subsequent pages. Numbers in the index correspond to the last two digits of the six-digit CID number. 


\section{Contents}

ix Conference Committee

$\mathrm{xi}$ The evolution of airborne chemical and radiological remote sensing for emergency and natural disaster response (Plenary Summary)

P. E. Lewis, National Geospatial-Intelligence Agency (United States)

\section{SAR APPLICATIONS I}

817902 Sentinel-1A and Sentinel-1B CSAR status (Invited Paper) [8179-01]

P. Snoeij, M. Brown, M. Davidson, B. Rommen, N. Floury, D. Geudtner, R. Torres, European Space Agency (Netherlands)

817903 Comparison of $L$ and $C$ band polarimetric SAR data for the retrieval of soil moisture in the Alps [8179-02]

L. Pasolli, Univ. degli Studi di Trento (Italy) and EURAC-Institute for Applied Remote Sensing (Italy); C. Notarnicola, EURAC-Institute for Applied Remote Sensing (Italy); L. Bruzzone, Univ. degli Studi di Trento (Italy); G. Bertoldi, G. Niedrist, U. Tappeiner, EURAC-Institute for Alpine Environment (Italy); M. Zebisch, EURAC-Institute for Applied Remote Sensing (Italy);

F. Del Frate, G. V. Laurin, Univ. degli Studi di Roma Tor Vergata (Italy)

817904 Soil moisture mapping using Sentinel 1 images: the proposed approach and its preliminary validation carried out in view of an operational product [8179-03]

S. Paloscia, S. Pettinato, E. Santi, Istituto di Fisica Applicata Nello Carrara (Italy); N. Pierdicca, L. Pulvirenti, Univ. degli Studi di Roma La Sapienza (Italy); C. Notarnicola, EURAC research (Italy); G. Pace, Advanced Computer Systems S.p.A. (Italy); A. Reppucci, Starlab (Spain)

817906 Retrieval of soil surface parameters via a polarimetric two-scale model in hilly or mountainous areas [8179-35]

A. Iodice, A. Natale, D. Riccio, Univ. di Napoli Federico II (Italy)

\section{SAR APPLICATIONS II}

817907 Integration of X-SAR observations with data of other remote sensing techniques: preliminary results achieved with Cosmo/SkyMed announcement of opportunity projects (Invited Paper) [8179-05]

F. Vespe, Agenzia Spaziale Italiana (Italy); L. Baldini, Istituto di Scienze dell'Atmosfera e del Clima, CNR (Italy); C. Notarnicola, EURAC research (Italy); C. Prati, Politecnico di Milano (Italy); S. Zerbini, Univ. di Bologna (Italy); G. Celidonio, Telespazio S.p.A. (Italy)

817908 Analysis of snow changes in alpine regions with X-band data: electromagnetic analysis and snow cover mapping [8179-06]

B. Ventura, T. Schellenberger, C. Notarnicola, M. Zebisch, EURAC-Institute for Applied Remote Sensing (Italy); V. Maddalena, R. Ratti, L. Tampellini, Carlo Gavazzi Space S.p.A. (Italy); J. Du, State Key Lab. of Remote Sensing Science (China) 
817909 Use of high-resolution SAR data for the monitoring of water resources in Burkina Faso [8179-07]

F. Ciervo, Univ. di Salerno (Italy); G. Di Martino, A. lodice, Univ. degli Studi di Napoli Federico II (Italy); Y. Koussoube, Univ. de Ouagadougou (Burkina Faso); M. N. Papa, Univ. di Salerno (Italy); D. Riccio, G. Ruello, I. Zinno, Univ. degli Studi di Napoli Federico II (Italy)

8179 OA An image acquisition planning tool for optimizing information content in image data of spaceborne SAR systems [8179-08]

H. Anglberger, S. Tailhades, H. Suess, Deutsches Zentrum für Luft- und Raumfahrt e.V. (Germany)

JOINT SESSION WITH CONFERENCE 8180: SAR DATA ANALYSIS I

8179 OB SAR-based sea traffic monitoring: a reliable approach for maritime surveillance [8179-09]

A. Renga, Univ. degli Studi di Napoli Federico II (Italy); M. D. Graziano, M. D'Errico, Seconda Univ. degli Studi di Napoli (Italy); A. Moccia, A. Cecchini, Univ. degli Studi di Napoli Federico II (Italy)

$81790 \mathrm{C}$ A novel paradigm for urban environment characterization using ascending and descending TerraSAR-X data [8179-10]

E. Angiuli, G. Trianni, Joint Research Ctr. (Italy); P. Gamba, Univ. degli Studi di Pavia (Italy)

\section{JOINT SESSION WITH CONFERENCE 8180: SAR DATA ANALYSIS II}

8179 OD An unsupervised method for quality assessment of despeckling: an evaluation on COSMO-SkyMed data [8179-11]

B. Aiazzi, Istituto di Fisica Applicata Nello Carrara (Italy); L. Alparone, F. Argenti, Univ. di Firenze (Italy); S. Baronti, Istituto di Fisica Applicata Nello Carrara (Italy); T. Bianchi, A. Lapini, Univ. di Firenze (Italy)

8179 OE Basis for optronic ScanSAR processing [8179-12]

L. Marchese, P. Bourqui, S. Turgeon, INO (Canada); B. Harnish, M. Suess, European Space

Research and Technology Ctr. (Netherlands); F. Châteauneuf, A. Bergeron, INO (Canada)

\section{SAR FOR MARITIME APPLICATIONS}

8179 OF The Gulf of Mexico oil rig accident: analysis by different SAR satellite images [8179-14] F. Del Frate, A. Giacomini, D. Latini, D. Solimini, Univ. degli Studi di Roma Tor Vergata (Italy); W. J. Emery, Univ. of Colorado at Boulder (United States)

8179 OG Oil detection in RADARSAT-2 quad-polarization imagery: implications for ScanSAR performance [8179-15]

A. Cheng, M. Arkett, T. Zagon, Canadian Ice Service (Canada); R. De Abreu, Canada Ctr. for Remote Sensing (Canada); D. Mueller, Carleton Univ. (Canada); P. Vachon, J. Wolfe, Defence Research and Development Canada, Ottawa (Canada) 
$8179 \mathrm{OH} \quad$ Multifractal analysis of oil slicks on SAR images [8179-16]

R. Coscione, G. Di Martino, A. Iodice, D. Riccio, G. Ruello, Univ. di Napoli Federico II (Italy)

\section{SAR FOR RISK ASSESSMENT AND EVALUATION}

817901 Monitoring flood evolution in agricultural areas using COSMO-SkyMed data: analysis of the Tuscany inundation of December 2009 (Invited Paper) [8179-17]

L. Pulvirenti, N. Pierdicca, Univ. degli Studi di Roma La Sapienza (Italy); M. Chini, Istituto Nazionale di Geofisica e Vulcanologia (Italy); L. Guerriero, Univ. degli Studi di Roma Tor Vergata (Italy)

8179 0J Detection of fault creep around NAF by InSAR time series analysis using PALSAR data [8179-18]

T. Deguchi, Nittetsu Mining Consultants Co., Ltd. (Japan)

8179 OK Neural networks for automatic seismic source analysis from DInSAR data [8179-19] M. Picchiani, F. Del Frate, G. Schiavon, Univ. degli Studi di Roma Tor Vergata (Italy); S. Stramondo, M. Chini, C. Bignami, Istituto Nazionale di Geofisica e Vulcanologia (Italy)

$8179 \mathrm{OL}$ Preliminary analysis of a correlation between ground deformations and rainfall: the Ivancich landslide, central Italy [8179-20]

F. Ardizzone, M. Rossi, Istituto Di Ricerca Per La Protezione Idrogeologica, CNR (Italy);

F. Calò, L. Paglia, M. Manunta, Instituto per il Rilevamento Elettromagnetico dell'Ambiente, CNR (Italy); A. C. Mondini, Istituto Di Ricerca Per La Protezione Idrogeologica, CNR (Italy) and Univ. degli Studi di Perugia (Italy); G. Zeni, Instituto per il Rilevamento Elettromagnetico dell'Ambiente, CNR (Italy); P. Reichenbach, Istituto Di Ricerca Per La Protezione Idrogeologica, CNR (Italy); R. Lanari, Instituto per il Rilevamento Elettromagnetico dell'Ambiente, CNR (Italy); F. Guzzetti, Istituto Di Ricerca Per La Protezione Idrogeologica, CNR (Italy)

8179 OM Comparative analyses of multifrequency PSI ground deformation measurements [8179-21] J. R. Sabater, J. Duro, A. Arnaud, D. Albiol, F. N. Koudogbo, Altamira Information (Spain)

\section{SAR AND MODELLING APPROACH}

8179 ON Dedicated SAR simulation tools for ATR and scene analysis [8179-22]

H. Hammer, K. Schulz, Fraunhofer-Institut für Optronik, Systemtechnik und Bildauswertung (Germany)

817900 Target detection by change for SAR imagery [8179-23]

C. J. Willis, BAE Systems (United Kingdom)

8179 OP Microwave remote sensing of natural stratification [8179-24]

P. Imperatore, A. Iodice, D. Riccio, Univ. di Napoli Federico II (Italy)

$81790 Q \quad$ Multiple reflections in SAR images of business districts [8179-25]

D. Di Leo, D. Riccio, Univ. degli Studi di Napoli Federico II (Italy) 
8179 OR Moving target imaging by both Ka-band and Ku-band high-resolution radars [8179-26] Y. Zhang, The Key Lab. of Microwave Remote Sensing (China); W. Zhai, The Key Lab. of Microwave Remote Sensing (China) and The Graduate Univ. of Chinese Academy of Sciences (China); X. Zhang, X. Shi, X. Gu, J. Jiang, The Key Lab. of Microwave Remote Sensing (China)

8179 OS Distinguishing ability analysis of compressed sensing radar imaging based on information theory model [8179-27]

$\mathrm{H}$. Jiang, The National Key Lab. of Science and Technology on Microwave Imaging (China) and National Astronomical Observatories (China) and Institute of Electronics (China); B. Zhang, The National Key Lab. of Science and Technology on Microwave Imaging (China) and Institute of Electronics (China); Y. Lin, The National Key Lab. of Science and Technology on Microwave Imaging (China) and National Disaster Reduction Ctr. of China (China); W. Hong, Y. WU, The National Key Lab. of Science and Technology on Microwave Imaging (China) and Institute of Electronics (China)

8179 OT Despeckling in SAR images by matching pursuit of subband coherent structures using the library of wavelet bases [8179-28]

Y. S. Bekhtin, A. A. Bryantsev, Ryazan State Radio Engineering Univ. (Russian Federation)

8179 OU Efficient and accurate algorithm for the evaluation of Kirchhoff scattering from fractal surfaces [8179-29]

A. Iodice, Univ. degli Studi di Napoli Federico II (Italy); S. Perna, Univ. degli Studi di Napoli Parthenope (Italy)

8179 OV Oil platform investigation by multi-temporal SAR remote sensing image [8179-30] C. Peng, J. Wang, D. Li, The Second Institute of Oceanography, SOA (China)

8179 OW Polarization scattering characteristics of some ships using polarimetric SAR images [8179-31]

J. Wang, Ocean Univ. of China (China) and The Second Institute of Oceanography, SOA (China); W. Huang, J. Yang, P. Chen, H. Zhang, The Second Institute of Oceanography, SOA (China)

$81790 \mathrm{X} \quad$ Application of sparse array and MIMO in near-range microwave imaging [8179-32] Y. Qi, Y. Wang, W. Tan, W. Hong, Institute of Electronics (China)

$81790 Z$ SAR image post-processing for the estimation of fractal parameters [8179-34] G. Di Martino, D. Riccio, G. Ruello, I. Zinno, Univ. di Napoli Federico II (Italy)

$817911 \quad$ Neural networks for oil spill detection using TerraSAR-X data [8179-39]

R. G. Avezzano, Univ. degli Studi di Roma Tor Vergata (Italy); D. Velotto, M. Soccorsi, Deutsches Zentrum für Luft- und Raumfahrt e.V. (Germany); F. Del Frate, Univ. degli Studi di Roma Tor Vergata (Italy); S. Lehner, Deutsches Zentrum für Luft- und Raumfahrt e.V. (Germany) 
817912 Numerical weather prediction models and SAR interferometry: synergic use for meteorological and INSAR applications [8179-40]

N. Pierdicca, Univ. degli Studi di Roma La Sapienza (Italy); F. Rocca, Politecnico di Milano (Italy); D. Perissin, Institute of Space and Earth Information Science (Hong Kong, China); R. Ferretti, E. Pichelli, Univ. degli Studi dell'Aguila (Italy); B. Rommen, European Space Research and Technology Ctr. (Netherlands); N. Cimini, Istituto di Metodologie per l'Analisi Ambientale (Italy)

817913 Exploring constraints and benefits of PSI technique for landslide detection and monitoring from space [8179-41]

C. Iasio, S. Schneiderbaver, EURAC-Institute for Applied Remote Sensing (Italy); V. Mair, C. Strada, Provincia Autonoma di Bolzano Alto Adige (Italy)

817914 Squint mode SAR raw data generation for moving ship on the ocean [8179-42] G. Diao, X. Xu, BeiHang Univ. (China)

817915 Evaluation of geometric accuracy and the features of TanDEM-X [8179-43] T. Nonaka, K. Imai, T. Hiramatsu, PASCO Corp. (Japan)

Author Index 
Proc. of SPIE Vol. $8179817901-8$

Downloaded From: https://www.spiedigitallibrary.org/conference-proceedings-of-spie on 26 Apr 2023 Terms of Use: https://www.spiedigitallibrary.org/terms-of-use 


\title{
Conference Committee
}

\author{
Symposium Chair \\ Karin Stein, Fraunhofer-Institut für Optronik, Systemtechnik und \\ Bildauswertung (Germany) \\ Symposium Co-Chair
}

Charles R. Bostater, Florida Institute of Technology (United States)

Conference Chairs

Claudia Notarnicola, EURAC research (Italy)

Simonetta Paloscia, Istituto di Fisica Applicata Nello Carrara (Italy)

Nazzareno Pierdicca, Università degli Studi di Roma La Sapienza (Italy)

Programme Committee

Richard Bamler, Deutsches Zentrum für Luft- und Raumfahrt e.V.

(Germany)

Fabio Covello, Agenzia Spaziale Italiana (Italy)

Mihai P. Datcu, Deutsches Zentrum für Luft- und Raumfahrt e.V.

(Germany)

Fabio Del Frate, Università degli Studi di Roma Tor Vergata (Italy)

Linda Marchese, INO (Canada)

Antonio Moccia, Università degli Studi di Napoli Federico II (Italy)

Francesco Nirchio, Agenzia Spaziale Italiana (Italy)

Fabio L. Rocca, Politecnico di Milano (Italy)

Emanuele Santi, Istituto di Fisica Applicata Nello Carrara (Italy)

Stefan Schneiderbauer, EURAC research (Italy)

David Small, Universität Zürich (Switzerland)

Session Chairs

SAR Applications I

Claudia Notarnicola, EURAC research (Italy)

SAR Applications II

Simonetta Paloscia, Istituto di Fisica Applicata Nello Carrara (Italy)

Joint Session with Conference 8180: SAR Data Analysis I

Claudia Notarnicola, EURAC research (Italy)

Joint Session with Conference 8180: SAR Data Analysis II

Lorenzo Bruzzone, Università degli Studi di Trento (Italy) 
SAR for Maritime Applications

Nazzareno Pierdicca, Università degli Studi di Roma La Sapienza (Italy)

SAR for Risk Assessment and Evaluation

Emanuele Santi, Istituto di Fisica Applicata Nello Carrara (Italy)

SAR and Modelling Approach

Claudia Notarnicola, EURAC research (Italy) 
Plenary Summary

\title{
The Evolution of Airborne Chemical and Radiological Remote Sensing For Emergency and Natural Disaster Response
}

\author{
Summary of the September 19, 2011 SPIE Remote Sensing Plenary Session Presentation by \\ Paul E. Lewis \\ National Geospatial-Intelligence Agency, United States of America
}

First responders, joint operations centers, and recovery and remediation personnel consider timely and affordable airborne chemical, radiological, imagery analysis, and related mapping products essential in the formulation of a complete understanding of an incident and its potential impact on adjacent communities, and for recovery and remediation. Airborne remote sensing provides the flexibility to produce incident specific products and conduct over-flights at the frequencies needed to provide timely and relevant information for recovery and remediation operations, optimization of resources during an event, and for the safety of emergency response personnel.

The utility of airborne chemical remote sensing became apparent to the EPA during a chemical plant explosion, which occurred in Sioux City, Iowa in December of 1994. The facility produced ammonium nitrate fertilizer, and also produced its own ammonia for use in the process. In late December an explosion occurred rupturing the main storage tank and spilling three million gallons of ammonia. This resulted in lethal vapor levels in and around the plant and created a plume of ammonia vapors estimated to be 35 miles long. Approximately 3,500 people were evacuated over a 50 square mile area. The EPA sent in vehicles with ground sampling crews dressed in Level A hazmat suits with 30 minute air packs to monitor the site. Due to heavy snow coverage on the ground and saturated soil conditions underneath the snow, all of the EPA vehicles became stuck. Ground sampling crews had to be rescued before air supplies ran out. Consequently, no monitoring of vapor levels was accomplished.

The lessons learned from responding to the chemical explosion in Sioux City, Iowa in 1994 prompted the EPA to begin evaluating the application of airborne remote sensing infrared and gamma ray spectroscopy for emergency responses involving chemical and radiological incidents. Concurrently, with the evaluation process to determine the performance and feasibility of implementing infrared and gamma ray spectroscopy in an airborne platform came the evolution of a set of core requirements for an airborne operational capability: Standoff chemical and gamma ray detection and identification with low false alarm rates; High resolution orthorectified day-night imagery; Airborne data collection under cloud ceilings; Rapid dispatch-wheels up in under one hour after activation; Automated data processing -real or near-real-time chemical data analysis; Direct integration of data and information to local incident commanders-local and federal joint operations centers; Data telemetry to and from the aircraft.

According to the EPA, in the United States there are approximately 123 facilities where a release of chemicals could threaten more than one million people. There are approximately 750 additional facilities where a chemical release could threaten more than a hundred thousand people.

In 2001, the EPA implemented the United States only civilian operational airborne chemical detection and identification capability called the Airborne $\underline{\text { Spectral }}$ Photometric Environmental $\underline{\text { Collection }}$ Technology (ASPECT) Program. Subsequently in 2003, the EPA and NGA agreed to collaborate in a cooperative research and development program focused on evolving the capabilities of the ASPECT Program to produce near-realtime state of the art chemical, radiological and imagery mapping emergency response products. 


\section{Airborne Spectral Photometric Environmental Collection Technology (ASPECT) Program The United States Only Airborne 24/7 Operational CIVILEmergency Response Chemical, Radiological, \& Imaging Mapping Capability}

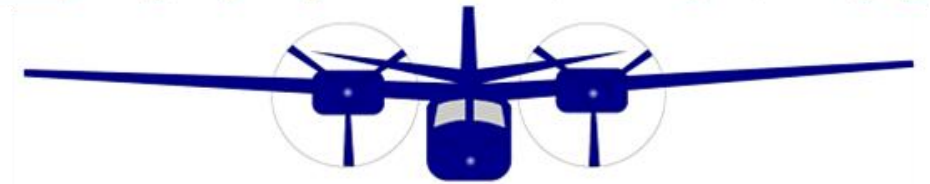

The ASPECT model of operation combines an airborne operational remote sensing suite with a research and development support team to insure that analysis and products are validated and verified scientifically and are reviewed and checked before release. The research and development support team collaboration between the EPA and NGA to evolve the capabilities of the ASPECT Program has resulted in the following significant accomplishments: Near-real-time automated onboard chemical detection and identification of 78 chemical compounds with low false alarm rates; Near-real-time information on plume direction and concentrations; Automated software producing day/night ortho-rectified imagery rapid response maps; Automated software producing gamma ray survey information maps onboard the aircraft; Data and information telemetry to and from the aircraft facilitating turn-around times and seamless integration of vital situational awareness information from the aircraft to first responders or joint operation centers in 5 to 15 minutes.

Since 2001 the ASPECT Program has provided essential information during 115 emergency, disaster, and homeland security related incidents ranging from chemical plant explosions and train derailments to fires, floods, hurricanes, and special events. The ASPECT Program played key roles in providing essential information to first responders and joint operations centers in response to the following historical events: The Shuttle Columbia break up during re-entry over Texas in February of 2003; Hurricane Katrina in August of 2005; The Deepwater Horizon Oil Spill disaster in the Gulf of Mexico from April-August 2010.

Over the past decade in over 115 responses, the ASPECT program has demonstrated the utility of having timely, cost-effective operational airborne chemical and radiological remote sensing information integrated seamlessly into to the local, state and federal emergency response and disaster recovery and remediation communities. What is needed next is the implementation of multiple aircraft strategically located throughout the United States so that ASPECT capabilities can be on the scene of a disaster or event in less than three hours. 